\title{
MODY Probability Ratios in Patients Diagnosed with Type 2 Diabetes Mellitus at a Young Age
}

\author{
Genç Yaşta Tip 2 Diabetes Mellitus Tanısı Almış Hastalarda \\ MODY Olasılık Oranları
}

\author{
Mirac Vural Keskinler $₫$, Ayse Naciye Erbakan $\odot$, Aytekin Oguz $\odot$
}

Ethics Committee Approval: This study approved by the Istanbul Medeniyet University Goztepe Training and Research Ethic Committee, 15 August 2017, 2017/0274.

Conflict of interest: The authors declare that they have no conflict of interest.

Funding: None.

Informed Consent: Not Applicable.
Cite as: Keskinler MV, Erbakan AN, Oguz A. MODY probability ratios in patients diagnosed with type 2 diabetes mellitus at a young age. Medeni Med J. 2020;35:290-4

\begin{abstract}
Objective: Maturity-onset diabetes of the young (MODY) is a non-rare group of monogenic inherited diabetes which is commonly confused with type 1 and type 2 diabetes. Due to high costs of genetic tests that provide a definitive diagnosis, some screening scales are used to identify the high-risk patients. In this study, we aimed to evaluate whether (MODY Probability Calculator [MPC]) which is one of the screening tests will be helpful in identifying our high-risk patients among young patients with type 2 diabetes

Method: The patients received the diagnosis of type 2 diabetes aged <35 years were included in the study. The anthropometric characteristics of the patients, the treatments they received at the time of diagnosis, and the current treatments were recorded by retrospectively scanning patient files. The patients with the diagnosis of type 1 diabetes having autoantibodies to the pancreas were excluded from the study. The probability of MODY was calculated using MPC..

Results: The mean age of 72 patients (40\% female) was $41.5 \pm 7.2$ years. Eighteen of the patients (25\%) were using insulin at the time of diagnosis. The mean $\mathrm{HbA} 1 \mathrm{c}$ was $8.6 \pm 2.2 \%$ and C-peptide was $2.35 \pm 1.52 \mathrm{ng} / \mathrm{ml}$. The mean MODY positive predictive score calculated by MPC for risk of MODY was 11.23 percent. There were 61 patients $(84.7 \%)$ with a risk of $\leq 20 \%$, 9 patients $(12.5 \%)$ with a risk of $20-50 \%$, and 2 patients $(2.8 \%)$ with $\geq 50 \%$. In the group with MODY PPV score $>20 \%$, the age of onset of diabetes and the body mass index was significantly lower than the others ( $p<0.05$, for both). There was no significant difference between current treatments of both groups.

Conclusion: It has been reported that MODY risk calculated by MPC may yield different results in different populations. The results of this study showed that $15 \%$ of our young-onset diabetes patients had an MPC score above 20 percent. Requesting MODY genetic tests in this $15 \%$ of the patient group can be presented as a practical suggestion.
\end{abstract}

Keywords: Maturity-onset diabetes, screening programs, diagnostic

Öz

Amaç: Gençlerde görülen erişkin tip diyabet (MODY), tip 1 ve tip 2 diyabetle karışan, monogenik geçişli, diyabetin nadir olmayan bir grubunu oluşturmaktadır. Kesin tanıyı sağlayan genetik testlerin maliyetlerinin yüksek olması nedeniyle yüksek riskli hastaları belirlemeye yönelik bazı tarama ölçekleri kullanılmaktadır. Biz bu çalıșmamızda diyabet polikliniğine bașvuran erken yaș tip 2 diyabet olgularında tarama testlerinden biri olan MODY Olasılık Hesaplayıcısının (MODY Probability Calculator [MPC]) yüksek riskli hastalarımızın belirlenmesinde yardımcı olup olmayacağını değerlendirmeyi amaçladık .

Yöntem: Otuz beş yașından önce tip 2 diyabet tanısı almış hastalar çalıșmaya alındı. Hastaların geriye dönük dosyaları incelenerek antropometrik özellikleri, tanı anında aldıkları tedaviler ve güncel tedavileri kaydedildi. Tip 1 diyabet tanılı veya pankreasa yönelik otoantikorları pozitif olan hastalar dışlandı. Hastalarda MPC kullanılarak MODY olma olasılığı hesaplandı.

Bulgular: Calışmada incelenen 72 hastanın (\%40'ı kadın), yaş ortalaması 41,5 7,2 yıldı. Hastaların 18'ine (\%25) tanı anında insülin başlanmıştı. Hastaların ortalama $H b A 1$ c değerleri $\% 8,6 \pm 2,2$, ortalama C-peptidleri ise $2,35 \pm 1,52 \mathrm{ng} / \mathrm{dl}$ idi. Hastaların MPC ile hesaplanan risklerinde ortalama MODY pozitif predikte edici değeri $\% 11,23$ idi. Riski $\leq \% 20$ olan 61 (\%84.7), \%20-50 arasında olan 9 (\%12.5), 250\% olan 2 (\%2.8) hasta mevcuttu. MODY PPV skoru >\%20 olan grupta, diyabet başlangıç yaşı ve vücut kitle indeksi diğerlerine göre anlamlı derecede düşüktü (her ikisi için de $p<0.05$ ). Her iki grubun mevcut tedavileri arasında fark yoktu.

Sonuç: MPC ile hesaplanan MODY riskinin farklı topluluklarda farklı sonuçlar verebileceği bildirilmiştir. Bu çalışmanın sonuçları, bizim genç başlangıçlı diyabet hastalarımızın \%15'inde MPC skorunun \%20'nin üzerinde olduğunu göstermiştir. MODY genetik testlerinin bu \%15'lik hasta grubunda istenmesi pratik bir öneri olarak sunulabilir.

Anahtar kelimeler: Maturity-onset diabetes, tarama programları, teşhis

(c) Copyright Istanbul Medeniyet University Faculty of Medicine. This journal is published by Logos Medical Publishing.

Licenced by Creative Commons Attribution-NonCommercial 4.0 International (CC BY-NC 4.0)
Received: 19 September 2020

Accepted: 7 December 2020

Online First: 25 December 2020

Corresponding Author: M.V. Keskinler

ORCID: 0000-0003-4863-9666

Istanbul Medeniyet University, Faculty of Medicine,

Department of Internal Medicine,

Istanbul, Turkey

miracvural@hotmail.com

A.N. Erbakan

ORCID: 0000-0002-9047-6808

A. Oguz

ORCID: 0000-0002-2595-5167

Istanbul Medeniyet University,

Faculty of Medicine,

Department of Internal Medicine,

Istanbul, Turkey 


\section{INTRODUCTION}

Monogenic diabetes is a type of hereditary diabetes with different subgroups, resulting from a defect in one of the genes involved in $\beta$ cell function, and constitutes $1-5 \%$ of all cases with diabetes. MODY (maturity-onset diabetes of the young), which is usually seen in early adulthood, is the most common form of monogenic diabetes. It is a non-insulindependent, autosomal dominant form of diabetes. As MODY has similar features with type 1 and type 2 diabetes, most patients with MODY are usually misdiagnosed as having these two most common types of diabetes and treated accordingly ${ }^{1-6}$. Over $80 \%$ of MODY cases occur as a result of heterozygous mutations in glucokinase (GCK), hepatocyte nuclear factor 1- $\alpha$ (HNF1A), and hepatocyte nuclear factor 4- $\alpha$ (HNF4A) genes ${ }^{7}$. Actual diagnosis is made by the detection of these specific gene mutations. Hence, it is not feasible to screen every patient due to high costs of genetic testing; various screening tests have been developed to identify patients who should be genetically tested for MODY. One of the tests to predict the possibility of MODY, which is known as MODY Probability Calculator (MPC), was developed by Shields et $\mathrm{al}^{8}$. They achieved quite good results in European patients with diabetes diagnosed under 35 years of age, in the differentiation of MODY and type 1 or type 2 diabetes. In this study, we aimed to test the probability of MODY in young type 2 diabetic patients who attended the diabetes outpatient clinic.

\section{MATERIAL and METHODS}

This observational clinical study was conducted on patients with type 2 diabetes who were diagnosed before 35 years of age and presented to the diabetes outpatient clinic in a university hospital between August 2017 and December 2019. Informed consent was obtained from all subjects included in the study. The study protocol was approved by the hospital ethics committee (2017/0274) and conducted in accordance with the Declaration of Helsinki.
The participants' records were retrospectively analyzed. Patients with antibody positivity (AntiGAD, anti-insulin, or islet cell antibody), who had a history of diabetic ketoacidosis or were diagnosed with secondary diabetes were excluded from the study. Anthropometric measurements (height, weight), age, duration of diabetes, and accompanying diseases were recorded. The patients were contacted by phone, and their detailed family histories were queried. The participants' initial medications at the time of diagnosis and the follow-up changes in their treatment were all recorded. Filed laboratory data (fasting glucose, Cpeptide, $\mathrm{HbA} 1 \mathrm{c}$, and TSH) were registered. Body mass indices (BMIs) were calculated as weight (in kilograms) divided by height (in square meters). Clinical characteristics of MODY was defined as monogenic diabetes that should be considered in individuals who have atypical features of diabetes younger than 35 years of age (more often aged $<25$ years), negative antibody titers, the presence of neonatal hypoglycemia, and/or multiple diabetic family members excluding characteristic type 1 or type 2 diabetes?

MODY Probability Calculator analysis was used to evaluate the probability of MODY and calculated based on an online formula available in www. diabetesgenes.org. In this analysis, the patients' current age, age at the time of diagnosis, gender, ongoing treatment, duration of insulin treatment if insulin was used, presence of a family history of diabetes, BMI, and $\mathrm{HbA} 1 \mathrm{c}$ levels were asked. The participants' collected data were used to calculate the probability of MODY whether the participants with complete data were antibody-negative.

\section{Statistics:}

Statistical analysis was performed by SPSS version 22 (SPSS Inc., Chicago, IL). Clinical and demographic characteristics were summarized by mean and standard deviation for continuous variables, and frequencies and percentages for categorical variables. The categorical variables were compared with chi-squared distribution. Differences 
between independent samples were evaluated by Mann-Whitney $U$ test. A $p$ value of $<0.05$ was considered as statistically significant.

\section{RESULTS}

A total of 72 patients were recruited for the study. Approximately $40 \%$ of the patients were female. The mean age of the patients was 41.5 years, and the average BMI was calculated as $30.3 \mathrm{~kg} / \mathrm{m}^{2}$. The respective number of patients had one $(n=30$; $41.7 \%)$, two $(n=24 ; 33.3 \%)$, and three or more $(\mathrm{n}=10 ; 13.9 \%)$ family members with diabetes. Twenty-two participants (30.6\%) had one parent with diabetes, whereas 15 participants (20.8\%) had mothers and siblings with diabetes. Onefourth of the participants $(n=18)$ were initially given insulin at the time of their diagnosis, but insulin treatment was stopped in nine of these patients in their subsequent follow-up.

The patients were currently treated with oral hypoglycemic agents (OHA, $n=40 ; 56.6 \%$ ), insulin $(n=11 ; 15.3 \%)$ or both OHA and insulin $(n=21$; 29.2\%) (Table 1). The participants had a mean HbA1c value of $8.6 \pm 2.16 \%$, and their mean Cpeptide was $2.35 \pm 1.52 \mathrm{ng} / \mathrm{dl}$. The laboratory findings of the patients are shown in Table 1. Of the 26 patients $(36.1 \%)$ with hypertension, 24 were taking antihypertensive agents. Antihyperlipidemic agents were used by $44.4 \%(n=32)$ of the patients. There was no difference between the current treatments of both groups.

The clinical features of these patients were entered into the MODY Probability Calculator at www.diabetesgenes.org, and the mean MODY Positive predictive value (PPV) score was calcu-

Table 1. Demographic features and the laboratory parameters of the patients.

\begin{tabular}{ll}
\hline & $\begin{array}{l}\text { Mean } \pm \text { SD } \\
\text { (min-max) }\end{array}$ \\
\hline Age (years) & $41.5 \pm 7.2(26-70)$ \\
Female gender & $29(\% 40.3)$ \\
Height (cm) & $167.50 \pm 10.23(150-195)$ \\
Weight (kg) & $85.32 \pm 18.08(53-140)$ \\
BMI (kg/m2) & $30.33 \pm 5.54(19.9-48.4)$ \\
Diabetes onset age(years) & $31.42 \pm 4.57(14-35)$ \\
Family history of diabetes (n(\%)) & $64(72)$ \\
Family members with diabetes (n(\%)) & \\
$\quad$ O-1 & $38(52.8)$ \\
$\quad>2$ & $34(47.2)$ \\
Family members with diabetes (n(\%)) & $13(18.1)$ \\
$\quad$ Mother (M) & $9(12.5)$ \\
$\quad$ Father (F) & $12(16.7)$ \\
Siblings (S) & $15(20.8)$ \\
$\quad$ M/F+S) & $4(5.6)$ \\
M+F & $11(15.3)$ \\
Other combinations & \\
(Grandfather or grandmother) & $18(25)$ \\
Insulin use at the onset (n(\%)) & \\
Current therapy & $40(55.6)$ \\
OHA & $11(15.3)$ \\
Insulin & $21(29.1)$ \\
OHA+insülin & $2.35 \pm 1.52(1.05-8.49)$ \\
C-Peptide (ng/dl) & $8.6 \pm 2.2(5.8-15)$ \\
HbA1c (\%) & \\
&
\end{tabular}

BMI: Body mass index, OHA: oral hypoglycemic agents

Table 2. Demographic, clinical, laboratory parameters and treatment of patients in two groups according to the MODY PPV.

\begin{tabular}{|c|c|c|c|}
\hline & $\begin{array}{l}\text { MODY PPV } \leq 20 \\
\text { Mean } \pm S D(\min -\max )\end{array}$ & $\begin{array}{l}\text { MODY PPV }>20 \\
\text { Mean } \pm S D(\text { min-max })\end{array}$ & $\mathbf{P}$ \\
\hline Diabetes onset age (years) & $31.84 \pm 4.48$ & $22.82 \pm 4.40$ & $0.014^{*}$ \\
\hline BMI $\left(\mathrm{kg} / \mathrm{m}^{2}\right)$ & 38.88 & 20.32 & $0.006^{*}$ \\
\hline Insulin use at the onset (n) & 18 & 0 & $0.037^{*}$ \\
\hline \multicolumn{4}{|l|}{ Current therapy (n) } \\
\hline OHA & 33 & 7 & \\
\hline Insulin & 9 & 2 & 0.841 \\
\hline OHA+insulin & 18 & 2 & \\
\hline $\mathrm{TSH}(\mathrm{mU} / \mathrm{ml})$ & 1.32 & 1.77 & 0.095 \\
\hline C peptid (ng/dl) & 2.44 & 1.83 & 0.159 \\
\hline
\end{tabular}

OHA: Oral hypoglycemic agents, BMI: Body mass index, TSH: Thyroid stimulan hormone, PPV; Positive predictive value. *Significant, $p<0.05$ 
lated as 11.23 percent. In the group with MODY PPV score $>20 \%$, the age of onset of diabetes and BMI were significantly lower and insulin use at the onset was significantly higher than the others (Table 2). For the participants aged 35 years or younger at diagnosis, PPV scores were $\leq 20 \%$ in $84.7 \%(n=61)$, between $20-50 \%$, in $12.5 \%(n=9)$ and $\geq 50 \%$ in only $2.8 \%(n=2)$ of the patients. Accordingly, among our patients with type 2 diabetes aged $<35$ years, medium, and high-risk patients for MODY constituted $15.3 \%$, and $2.8 \%$ of our patient population.

\section{DISCUSSION}

For our patients with diabetes who were 35 years or younger at diagnosis, we found the possibility of MODY as $2.8 \%$ with a probability of $\geq 50 \%$, using the MODY probability calculator. The selection of patients with diabetes who are negative for pancreatic autoantibodies and have adequate $C$ peptide levels for the risk assessment of MODY further increases the possibility of MODY.

In young patients, type 1 diabetes is the most prevalent form, but some of the young patients who are using insulin and are treated as type 1 diabetes actually have MODY. As the molecular genetic testing necessary for the confirmation of MODY is expensive, it is not feasible to screen every suspected patient. Therefore, various studies were performed to develop screening tests to identify patients with a high possibility of MODY to be used as the first step. These studies were carried out both in pediatric and adult patients, exploring to find the relevant parameters to be used to screen MODY. The probability of MODY would be low in patients with high BMI, metabolic syndrome, GAD antibody positivity, and the lack of family history of diabetes unless with a high clinical suspicion genetic testing was performed ${ }^{10}$. In our study, all participants were negative for pancreatic autoantibodies. Forty-two percent of our patients had more than two family members with diabetes. Approximately one-third of the patients had a strong family history of diabetes, affecting their siblings and also at least one of their parents. In young patients who are initially treated with insulin at the time of their diagnosis, it is difficult to determine whether their actual diagnosis is type 1 diabetes or MODY. For these patients, the calculation of urinary C-peptide/creatinine ratio (urinary C-peptide creatinine ratio [UCPCR]) and the assessment of pancreatic autoimmunity with anti-GAD/anti-IA antibodies have diagnostic high specificity and sensitivity ${ }^{11}$. As an obstacle, our patients' initial UCPCR were not measured at the time of their diagnosis. Therefore, we delegated C-peptide levels with UCPCR to compensate, and only patients with high C-peptide levels were included in the study. Twenty-five percent of the participants used insulin at the onset of their diabetes, and remarkably only half of them were still using insulin at the time of our evaluation.

\section{Limitations:}

In various countries, the prevalence of MODY was similar; $0.7 \%$ if the patients were prescribed insulin in the first six months of their diagnosis, whereas it was $4.6 \%$ when they were not. The prevalence of MODY in our country has not been documented yet; therefore, the actual probability ratios might be different from our calculations. For example, diagnostic genetic tests indicated that patients with MODY had positive predictive score of $>25 \%$ in the UK, but if a difference in patients' treatment is anticipated then they can be tested even if they have a lower MPC score. If we choose higher threshold values for genetic testing, then we will have proportionally higher number of patients diagnosed with MODY. Still, the likelihood of skipping actual MODY patients would also be high.

A further limitation is that our high-risk patients were not genetically tested. However, our aim was to draw attention to the fact that high-risk patients can be recognized by simple screening tests in outpatient settings, even without the 
genetic tests are performed. Among our study group, which consisted of young and auto-antibody negative patients with diabetes, we directed patients with a positive predictive score of $50 \%$ and higher for further testing, which appears to be a reasonable cut-off score to keep positive and negative predictive scores at optimal levels. In a study in which MPC was evaluated together with MODY genetic test results in a multiethnic population, MODY probability rate calculated by MPC was higher than $50 \%$ in patients with glucokinase gene mutation. Therefore $50 \%$ was taken as cutoff the possible diagnosis of MODY ${ }^{12}$.

The fact that routine diagnostic molecular genetic testing cannot be performed to all patients due to their high costs poses a critical obstacle in diagnosing real MODY patients. This impediment is a real concern for our country and the rest of the world. Even though MODY treatment significantly differs from the treatment of type 1 diabetes, most MODY patients are often misdiagnosed and managed as patients with type 1 diabetes which poses a real problem and urges the need to find quick and practical solutions. The MODY probability calculator that we used in our study has also been recommended in various studies.

In our study, the high-risk patients for MODY was estimated as $2.8 \%$, comparable to the other populations. It should be kept in mind that MODY Probability Calculator is a screening test; therefore, it should be followed by molecular genetic testing as the next step. It can be considered as a valuable tool that may be used particularly in busy outpatient clinics to prioritize patients to whom genetic testing for the diagnosis of MODY is requested. A probability of more than $25 \%$ was suggested as a reasonable level at which genetic testing might be offered ${ }^{13}$. The result of this study showed that $15 \%$ of our young-onset diabetes patients had an MPC score above 20 percent. Prioritizing the request for MODY genetic tests for patients in this group can be considered as a practical suggestion.

\section{REFERENCES}

1. Tattersall RB, Fajans SS. A difference between the inheritance of classical juvenile-onset and maturity-onset type diabetes of young people. Diabetes. 1975;24:44-53. [CrossRef]

2. Gat-Yablonski G, Shalitin S, Phillip M. Maturity onset diabetes of the young--review. Pediatr Endocrinol Rev. 2006;Suppl 3:514-20.

3. McDonald TJ, Colclough K, Brown R, et al. Islet autoantibodies can discriminate maturity-onset diabetes of the young (MODY) from Type 1 diabetes. Diabet Med. 2011;28:1028-33. [CrossRef]

4. Thanabalasingham G, Owen KR. Diagnosis and management of maturity onset diabetes of the young (MODY). BMJ. 2011;343:d6044. [CrossRef]

5. Dussoix P, Vaxillaire M, Iynedjian PB, et al. Diagnostic heterogeneity of diabetes in lean young adults: classification based on immunological and genetic parameters. Diabetes. 1997;46:622-31. [CrossRef]

6. Fajans SS, Bell GI, Polonsky KS. Molecular mechanisms and clinical pathophysiology of maturity-onset diabetes of the young. N Engl J Med. 2001;345:971-80. [CrossRef]

7. Ellard S, Bellanné-Chantelot C, Hattersley AT; European Molecular Genetics Quality Network (EMQN) MODY group. Best practice guidelines for the molecular genetic diagnosis of maturity-onset diabetes of the young. Diabetologia. 2008;51:546-53. [CrossRef]

8. Shields BM, McDonald TJ, Ellard S, Campbell MJ, Hyde C, Hattersley AT. The development and validation of a clinical prediction model to determine the probability of MODY in patients with young-onset diabetes. Diabetologia. 2012;55:1265-72. [CrossRef]

9. Shields BM, Hicks S, Shepherd MH, Colclough K, Hattersley AT, Ellard S. Maturity-onset diabetes of the young (MODY): how many cases are we missing? Diabetologia. 2010;53:2504-8. [CrossRef]

10. Thanabalasingham G, Pal A, Selwood MP, et al. Systematic assessment of etiology in adults with a clinical diagnosis of young-onset type 2 diabetes is a successful strategy for identifying maturity-onset diabetes of the young. Diabetes Care. 2012;35:1206-12. [CrossRef]

11. Besser RE, Shepherd MH, McDonald TJ, et al. Urinary Cpeptide creatinine ratio is a practical outpatient tool for identifying hepatocyte nuclear factor 1-\{alpha\}/hepatocyte nuclear factor 4-\{alpha\} maturity-onset diabetes of the young from long-duration type 1 diabetes. Diabetes Care. 2011;34:286-91. [CrossRef]

12. Tarantino RM, Abreu GM, Fonseca ACP, et al. MODY probability calculator for GCK and HNF1A screening in a multiethnic background population. Arch Endocrinol Metab. 2020;64:17-23. [CrossRef]

13. Njølstad PR, Molven A. To test, or not to test: time for a MODY calculator? Diabetologia. 2012;55:1231-4. [CrossRef] 